\title{
A feasibility study on organic lotus pollen tea as consumer product
}

\author{
Duangtip Hongsamoot ${ }^{1}$, Suvarin Bumroongsook ${ }^{2 *}$
}

${ }^{1}$ The Medical and Vaccine Administration Fund, The National Health Security Office, The Government Complex Building B, $4^{\text {th }}$ Floor120 Moo 3 , Chaengwattana Road, Laksi District, Bangkok 10210, Thailand; 'Faculty of Agricultural Technology, King Mongkut's Institute of Technology Ladkrabang, Bangkok 10520, Thailand

\section{A B S T R A C T}

Lotus pollen tea, in particular, contains potent antioxidants. The first step of this study was the screening for 3 desired qualities of 4 varieties of lotus (Nelumbonucifera Gaertn): Sattabongkutt, Buntharik, Sattabutt, and Patum. The 3 desired qualities were as follows: High pollen yield; potent antioxidant activity; and favorable aroma, flavor, and color to a panel of testers. The results of the screening were the following: one, the pollen productions of a flower of each of the 4 varieties stated above were $1.28,3.11,0.43$, and $1.83 \mathrm{gm}$, respectively; two, Buntharik had the highest antioxidant capacity at a trolox equivalent of $499.48 \mu \mathrm{g} / \mathrm{ml}$ or $59.94 \mathrm{mg} / \mathrm{serving}$ and at a total polyphenol equivalent of gallic acid of $63.26 \mu \mathrm{g} / \mathrm{ml}$ or $7.59 \mathrm{mg} / \mathrm{serving}$; and three, the highest-rated variety in a hedonic test of overall preference was Buntharik. Thus, the Buntharik tea was chosen for the consumer acceptance studies conducted with 90 tea testers with equal number of males and females. The finding was found that males preferred this tea over females; panelists over 30 years old gave the highest score on overall preference; their level of acceptance was fairly acceptable, at $50 \%$, but their purchase intention was lower, at $27.78 \%$.

Keywords: Antioxidant capacity; Consumer acceptance test; Organic lotus pollen tea; Total polyphenol

\section{INTRODUCTION}

Sacred lotus (Nelumbonucifera (Gaertn.)) has long been honored the queen of aquatic plants in Thai culture. In Thailand, there are 4 common varieties of lotus: Sattabutt (white double), Sattabongkot (pink double), Buntharik (white single), and Patum (pink single). It is a widespread ornamental plant used especially in religious ceremony. Lotus cultivation is frequently plagued by thrip infestation, especially by the species Frankliniella schultrei (Trybom). Both the adults and larvae of this insect species ferociously attack lotus petal and pollen, forcing growers to use insecticide heavily. Even so, thrips are very difficult to control due to their prevalence and difficultto-locate habitat (Mungnimitr and Bumroongsook, 2007). In international trade, where export of lotus flowers requires them to be pest free, thrips are a major cause for quarantine (Walsh et al., 2005). Consequently, growers have to strictly control them, both before and after harvest, yet it is still very difficult to meet the regulations of the major importing countries. An alternative to export whole lotus flowers is to export them as pest-free herbal tea.

Lotus, all parts of it, is well known for its medical benefits. A wide range of pharmacological effects from different parts of this plant has been reported. According to Department of Medical Science (2004), the pollen protects against DNA mutation, promotes enzyme activity, destroys toxic substances, mildly decreases blood sugar, and nurtures the heart. The brownish yellow filament of the pollen has various therapeutic benefits to the heart, spleen, and liver. Hence, numerous traditional medicines have lotus pollen as an essential ingredient in their formularies. The pollen also contains several flavonoids such as quercetin, luteolin, isoquercitrin, and luteolin-glucoside. Flavoniods are found in edible plants (Miean and Mohamed, 2001). These substances are reported to benefit health (Tokuşoğlu et al., 2003). Nowadays, lotus pollens are increasingly being used as natural health supplements. They possess antioxidant properties when brewed in hot water. Total polyphenol

\footnotetext{
${ }^{*}$ Corresponding author:

Suvarin Bumroongsook, Faculty of Agricultural Technology, King Mongkut's Institute of Technology, Ladkrabang, Bangkok 10520, Thailand. Tel: 66813471805, Fax: 6623298523, E-mail: kbsuvari@kmitl.ac.th
} 
content and antioxidant activity are parameters of the tea's antioxidative quality (Anesini et al., 2008).

The Department of Thai Foreign Trade Affair has found that imported consumer household goods including drinks and tea are growing steadily, causing an unbalanced trade. Therefore, this is a good opportunity for lotus growers to offer lotus tea, full of beneficial flavonoids, as an alternative to imported beverages that offer no health benefit. In addition, healthy lotus tea fittingly caters to the need for healthy food products currently in high demand by the top-tiered consumer markets with high purchasing power such as those in the European Community, Japan, and the United States (Newswit, 2007). Therefore, organic lotus pollen tea is a good value-added product that can bring in more steady income to lotus growers.

\section{MATERIALS AND METHODS}

\section{Pollen production and sample preparation}

Four varieties of lotus: Sattabutt, Sattabongkutt, Buntharik, and Patum were grown in a farm at the KMITL campus in Bangkok. The lotuses were grown organically, without any chemicals, by techniques such as cutting full bloom flowers and leaves above the water to prevent thrip and caterpillar infestations and cleaning up of weeds and grasses to prevent insects from laying eggs and harboring in the area around the farm (Bumroongsook, 2003). Green manure and compost were added to prevent nutrient deficiency (Malhi, 2009). At the age of 10 days, the flowers were hand-picked in the morning and their sizes, weights, and the amounts of pollens collected were recorded. Thrip contamination was also examined. The collected pollens were dried in a shade for two days and removed of any pest contamination before they were ground into powder. The powder was then packaged into tea bags: $1.0 \mathrm{~g}$ in each $5 \times 5 \mathrm{~cm}$ tea bag.

\section{Hedonic test}

Thirty people who have drunk lotus tea before were recruited as testers. Lotus pollen tea made from Sattabutt, Sattabongkutt, Buntharik, and Patum varieties were evaluated on their flavor, aroma and color. The testers' preferences of these attributes and their overall preference were graded on a 9 point hedonic scale, from extremely dislike to extremely like. Analysis of variance were conducted on the sample mean scores of these preferences. Statistically significant attributes were further analyzed for the mean differences using Duncan Multiple Range test at $\mathrm{P}<0.05$.

\section{Antioxidant activity}

The DPPH scavenging test used was the method of BrandWilliam et al. (1995). One bag of tea was soaked in $120 \mathrm{ml}$ of hot water for 2 minutes. Then, $1 \mathrm{ml}$ of the brewed tea was added to $1 \mathrm{ml}$ of DPPH solution. Next, the mixture was incubated for 30 minutes. The absorbance of the mixture was measured at $517 \mathrm{~nm}$ with a Spekol 2000 UVvis spectrophotometer (AnalytikGena, Germany). Distilled water was used as blank and trolox as standard. Percentage of inhibition was calculated using the following equation:

$$
\% \text { inhibition }=\left(\mathrm{Abs}_{\mathrm{t}=0}-\mathrm{Abs}_{\mathrm{t}=30}\right) / \mathrm{Abs}_{\mathrm{t}=0} * 100 \text {, }
$$

where

$\mathrm{Abs}_{\mathrm{t}=0}$ was the absorbance of DPPH at time $=0 \mathrm{~min}$, $\mathrm{Abs}_{\mathrm{t}=30}$ was the absorbance of DPPH after 30 minutes of incubation.

Antioxidant activity was expressed as $\mu \mathrm{g}$ of trolox equivalent per $\mathrm{ml}$ or $\mathrm{mg}$ of trolox equivalent per serving.

\section{Total phenolic content analysis}

Total phenolic content was determined by the FolinCiocalteau method. Each bag of tea was extracted with $120 \mathrm{ml}$ of water at $80^{\circ} \mathrm{C}$ for 2 minutes. Its total polyphenol content was determined by a modified method of Singleton et al. (1999). The total phenolic content of the tea was measured by using Folin-Ciocalteau reagent. Dilute reagent was mixed with a tea sample and left sitting at room temperature for 5 minutes. Then, $2 \%$ sodium carbonate was added, and the mixture incubated for 15 minutes at room temperature. The absorbance of the tea sample was measured at $765 \mathrm{~nm}$ with a Spekol 2000 UV-vis spectrophotometer (Analytik Gena, Germany). Distilled water was used as blank and gallic acid as standard. The results were reported as $\mu \mathrm{g}$ of gallic acid equivalent $/ \mathrm{ml}$ and $\mathrm{mg}$ of gallic acid equivalent/serving.

\section{Consumer acceptance test}

A panel of 90 tea testers was recruited from the Ladkrabang community, Bangkok, to participate in this study. These testers were chosen according to the following three criteria: they were between 18-65 years old; they drank tea at least once a week; and the number of male and female testers in each age group should be equal. The panelists were divided into 3 age groups (less than 20, 20-30, and more than 30 years of age). Each group consisted of 30 persons with equal number of males and females. The Buntharik pollen tea was evaluated on the testers' preferences for its aroma, flavor, color, nutritional value, and on their overall preference, using a 9 point intensity scale anchoring at extremely dislike to extremely like. These panelists were also asked to respond to items of a questionnaire at the end of the test. The items covered demographic and socioeconomic information, tea drinking behavior, and tea product acceptance. 
Analyses of variance were conducted on the sample mean scores for aroma, flavor, color, nutritional value, and overall preference. Statistically significant attributes were further analyzed for the mean differences using Duncan Multiple Range Test at $\mathrm{P}=0.05$. The analysis of the responses to the questionnaire only focused on obtaining frequencies and descriptive statistics. Cross tabulations were used to explore whether special relationships existed.

\section{RESULTS AND DISCUSSION}

This study shows that Sattabongkutt flower was the heaviest, followed by Sattabutt, Buntharik, and Patum. The widths of Sattabongkutt, Buntharik, Sattabutt, and Patum flowers were 10.03, 7.12, 5.75 and $5.17 \mathrm{~cm}$, respectively. Buntharik flower was the longest at $12.95 \mathrm{~cm}(\mathrm{p}<0.05)$, followed by Sattabongkutt, Patum, and Sattabutt. The amounts of collected pollens were significantly different among the four lotus varieties $(\mathrm{p}<0.05)$; Buntharik had the highest amount of them, weighing 3.1 gm while Patum, Sattabongkutt, and Sattabutt had 1.83, 1.28 and $0.43 \mathrm{~g}$, respectively. Thrip contamination on pollens, of adults and larvae of F. schultzei, was monitored, and Buntharik pollens were found to be most contaminated at 59.80 ( $\mathrm{p}<0.05$ ), followed by Patum, Sattabongkutt, and Sattabutt at 8.40, 4.13 and 2.67, respectively (Table 1). Pleansri and Bumroongsook (2013) found heavy infestation of thrips in the middle part of a lotus flowers where lotus pollen was located, thus pollen was easily contaminated by thrips population. Moreover, F. schultrei preferred Buntharik to other varieties. Laborious work of picking up dead thrips from dried pollens was needed. Minor damage of an organic product by pests should be perceived positively by consumers(Hadyanyah, 2009).

The highest antioxidant capacity among those of the four pollen teas was found in Buntharik tea. It was equal to a trolox equivalent of $499.48 \mathrm{~g} / \mathrm{ml}$ or $59.94 \mathrm{mg} /$ serving. This finding confirmed with Thongrungroj (2007) that Butharik pollen had antioxidant capacity more than the other varieties. The antioxidant activity is to scavenge free radicals and benefit human health, and be associated with the prevention of cardiovascular diseases, anticancer and anti-aging (Verlangieri et al., 1985). Moreover, its total polyphenol content was an equivalent of gallic acid $63.26 \mu \mathrm{g} / \mathrm{ml}$ or $7.59 \mathrm{mg} /$ serving (Table 2). The antioxidant capacity and total phenolic content of the Buntharik tea was much higher than those of other varieties. The chemical composition of lotus pollen is complex includes polyphenol, quercitin, luteolin, isoquercitin, luteolin glucoside, volatile oil, alkaloid, and unidentified compounds (Deparment of Medical Science, 2004; Thongrungroj 2007). Quercithin, a flavonoid glycoside, had antioxidant properties (Zhang et al, 2011). It is considered as one of the most prominent dietary antioxidants and it was found in fruits and vegetables and excerted beneficial health benefit (Boot et al., 2008). Polyphenol is an interesting group and some plant phenolic contents has strong antioxidant capacity (Cabrera et al., 2003; Karori et al., 2007). The plant crude extract could prevent the occurrence of most degenerative diseases due to its high phenolic content, and, its high antioxidant activity (Beltrán-Orozco1, 2013). Nevertheless, natural antioxidants are the result of multiple factors and its antioxidant capacity cannot only be associated to the phenolic content (Arazo et al., 2011)

The results of the consumer hedonic test of 4 different lotus teas showed that, in the category of overall preference, most testers preferred ones made from Buntharik and Patum pollens. Most of them also preferred the aroma and the flavor of these two teas (Table 3). There were no significant differences among preferences on color $(\mathrm{p}>0.05)$.

Table 1: Amounts of pollens collected from four lotus varieties and numbers of their contaminating thrips

\begin{tabular}{lccccccc}
\hline Variety & \multicolumn{3}{c}{ Flower $^{1}$} & $\begin{array}{c}\text { Pollen }^{1} \\
(\mathbf{g m})\end{array}$ & \multicolumn{2}{c}{$\begin{array}{c}\text { Frankliniella } \\
\text { schultzei }\end{array}$} \\
\cline { 2 - 4 } \cline { 7 - 8 } & $\begin{array}{c}\text { Wt } \\
\text { (gm) }\end{array}$ & $\begin{array}{c}\text { Width } \\
(\mathbf{c m})\end{array}$ & $\begin{array}{c}\text { Length } \\
(\mathbf{c m})\end{array}$ & & $\begin{array}{c}\text { No. of } \\
\text { adults }\end{array}$ & $\begin{array}{c}\text { No. of } \\
\text { larvae }\end{array}$ \\
\hline Sattabutt & $38.10^{\mathrm{b}}$ & $5.75^{\mathrm{bc}}$ & $5.23^{\mathrm{c}}$ & $0.43^{\mathrm{d}}$ & $4.4^{\mathrm{c}}$ & $4.20^{\mathrm{bc}}$ \\
Sattabongkutt & $110.38^{\mathrm{a}}$ & $10.30^{\mathrm{a}}$ & $9.38^{\mathrm{b}}$ & $1.28^{\mathrm{c}}$ & $19.00^{\mathrm{b}}$ & $2.80^{\mathrm{c}}$ \\
Buntharik & $33.40^{\mathrm{b}}$ & $7.12^{\mathrm{b}}$ & $12.95^{\mathrm{a}}$ & $3.11^{\mathrm{a}}$ & $59.80^{\mathrm{a}}$ & $12.40^{\mathrm{a}}$ \\
Patum & $23.86^{\mathrm{c}}$ & $5.34^{\mathrm{c}}$ & $9.28^{\mathrm{b}}$ & $1.83^{\mathrm{b}}$ & $5.40^{\mathrm{c}}$ & $8.40^{\mathrm{ab}}$ \\
\hline
\end{tabular}

${ }^{1}$ Means with the same letter designation in the same column are not statistically significantly different $(p=0.05$, DMRT $)$

Table 2: Antioxidant capacity and total polyphenol content of organic lotus pollen teas from four varieties of lotus

\begin{tabular}{lccccc}
\hline Variety & \multicolumn{2}{c}{$\begin{array}{c}\text { Antioxidant capacity } \\
\text { (Trolox equivalent) }\end{array}$} & & \multicolumn{2}{c}{$\begin{array}{c}\text { Total polyphenol } \\
\text { content (GAE) }\end{array}$} \\
\cline { 2 - 3 } \cline { 5 - 6 } & $\boldsymbol{\mu g} / \mathbf{m l}^{1}$ & mg/serving & & $\boldsymbol{\mu g} / \mathbf{m l}^{1}$ & mg/serving \\
\hline Sattabutt & $6.25^{\mathrm{b}}$ & 0.75 & & $8.54^{\mathrm{d}}$ & 1.02 \\
Sattabongkutt & $31.95^{\mathrm{b}}$ & 3.83 & & $22.73^{\mathrm{c}}$ & 2.73 \\
Buntharik & $499.48^{\mathrm{a}}$ & 59.94 & & $63.26^{\mathrm{a}}$ & 7.59 \\
Patum & $7.43^{\mathrm{b}}$ & 0.89 & & $33.32^{\mathrm{b}}$ & 3.99 \\
\hline
\end{tabular}

${ }^{1}$ Means with the same letter designation in the same column are not statistically significantly different $(p=0.05, D M R T)$

Table 3: Comparison of consumer ratings ${ }^{1}$ of organic lotus pollen teas from four varieties of lotus

\begin{tabular}{lcccc}
\hline Attribute & Sattabutt & Sattabongkutt & Buntharik & Patum \\
\hline Aroma & $6.50^{\mathrm{ab}}$ & $6.33^{\mathrm{b}}$ & $7.20^{\mathrm{a}}$ & $7.16^{\mathrm{a}}$ \\
Flavor & $6.36^{\mathrm{ab}}$ & $5.83^{\mathrm{b}}$ & $6.97^{\mathrm{a}}$ & $6.90^{\mathrm{a}}$ \\
Color & 7.40 & 7.07 & 6.93 & $6.86^{\text {ns }}$ \\
Overall preference & $6.43^{\mathrm{ab}}$ & $5.87^{\mathrm{b}}$ & $7.03^{\mathrm{a}}$ & $6.77^{\mathrm{a}}$ \\
\hline
\end{tabular}

${ }^{1}$ Rating based on a 9 point hedonic scale where $1=$ extremely dislike, $5=$ neither like nor dislike, and $9=$ extremely like. ${ }^{2}$ Means with the same letter designation in the same row are not statistically significantly different $(p=0.05$, DMRT). " nsRatings on this attribute was not significantly different at $\mathrm{P}<0.05$ 
Based on the above information, we conclude that Buntharik pollen tea is the healthiest because of its highest antioxidant capacity and total phenolic content. Buntharik flowers also gave the highest pollen yield, and Buntharik tea achieved the highest hedonic rating.

\section{Product acceptance}

According to gender, the results showed that, overall, males preferred lotus pollen tea more than females did; however, their preferences for aroma, flavor, or color of the tea were not different. According to age, testers 30 years old and over preferred this tea the most, followed by the ones between 20 and 30 years old and those less than 20 year old, in that order (Table 4). Out of the total of 90 purposedly chosen panelists, 45 were females and 45 were males. They were grouped according to their ages into 3 groups (<aged 20, $20-30$, and $>30$ or over) with equal representation from both genders (Table 5). They were also grouped according to their income into 3 groups. The biggest group, at $44.45 \%$ of the total number of testers, had members whose incomes were in the range of 10,000-30,000 baht; the next biggest group, at $31.11 \%$, had members with more than 30,000 baht income; and, the smallest group, at $22.44 \%$, was those with income between 5,000-10,000 baht (Table 5).

The testers were asked to specify the type of tea that they have been drinking. Of all the panelists, $45.56 \%$ responded that they drank green tea, $31.11 \%$ drank

\begin{tabular}{|c|c|c|c|c|c|}
\hline \multirow[t]{2}{*}{ Attributes } & \multicolumn{2}{|c|}{ Gender $^{1}(n=45)$} & \multicolumn{3}{|c|}{ Age (years) ${ }^{1}(n=30)$} \\
\hline & Male & Female & $<20$ & $20-30$ & $>30$ \\
\hline Aroma & 6.36 & $6.68^{\text {ns }}$ & $5.90^{b}$ & $6.43^{b}$ & $7.23^{a}$ \\
\hline Flavor & 5.86 & $5.93^{\text {ns }}$ & $5.30^{b}$ & $5.73^{b}$ & $6.73^{\mathrm{a}}$ \\
\hline Color & 7.48 & $7.46^{\mathrm{ns}}$ & 7.26 & 7.30 & $7.86^{\text {ns }}$ \\
\hline Nutritional value & 7.51 & $6.95^{\mathrm{ns}}$ & 7.10 & 7.20 & $7.40^{\text {ns }}$ \\
\hline Overall preference & $6.44^{\mathrm{a}}$ & $5.68^{b}$ & $5.57^{\mathrm{b}}$ & $6.17^{\mathrm{ab}}$ & $6.47^{a}$ \\
\hline
\end{tabular}

${ }^{1}$ Means with the same letter designation in the same row are not statistically significant different $(p=0.05, D M R T),{ }^{n s}$ Ratings on these attributes were not significantly different at $p=0.05$

$\begin{aligned} & \text { Table 5: Demographic and socioeconomic data of the } \\
& \text { panelists }(\mathbf{n}=90)\end{aligned}$
\begin{tabular}{lcc} 
Population characteristics & Frequency & Percentage \\
\hline $\begin{array}{l}\text { Gender } \\
\text { Male }\end{array}$ & 45 & \\
Female & 45 & 45 \\
Age (years) & & 45 \\
$\quad<20$ & 30 & 33.33 \\
$20-30$ & 30 & 33.33 \\
$>30$ & 30 & 33.34 \\
Income/month (baht) & & \\
$<5,000$ & 0 & 0.00 \\
5,000-10,000 & 22 & 24.44 \\
10,000-30,000 & 40 & 44.45 \\
$>30,000$ & 28 & 31.11 \\
\hline
\end{tabular}

Chinese tea, $16.67 \%$ drank instant tea, and the remaining $6.66 \%$ drank other types of tea. Tea-drinking time was classified into 4 categories (shown with the percentage of drinkers):before 10:00 (16.67\%), 10:00-13:00 (41.11\%), 13:01-17:00 (31.78\%), and 17:01-20:00 (4.44\%). As for how many testers drank tea at what frequency, $13.33 \%$ of the panelists drank it 1-2times a week, $51.11 \%$ drank between 3-5 times, and $35.56 \%$ drank more than 5 times. The panelists' responses indicated that $80 \%$ of them bought their tea by themselves and $20.00 \%$ of them got their tea by other means. The panelists'responses to the question of at what place they bought their tea were the following: mostly at supermarkets $(67.78 \%)$, convenient stores $(13.33 \%)$, co-op food stores $(8.89 \%)$, grocery stores $(5.56 \%)$, and other places (4.44\%) (Table 6). As for the level of acceptance indicated by the panelists, half of them responded that the tea was fairly acceptable, $16.67 \%$ very acceptable, $24.44 \%$ just acceptable, and $8.89 \%$ not acceptable. On the question whether they would buy the tea if a box of 20 tea bags was on the market for 50 baht, $27.78 \%$ of the panelists indicated that they would buy the product, $31.11 \%$ would not, and $41.11 \%$ was uncertain whether they would (Table 7). Purchase intention is one of the components of consumer cognitive behavior on how an individual intends to buy a specific product. The organic lotus pollen tea products is a healthy drink and less harmful to the environment than their non-organic equivalents. It is assumed that rational considerations will favor the

Table 6: Types of tea that has been consumed by the panelists $(n=90)$ and their tea consumption behavior

\begin{tabular}{lcc}
\hline Behavior & Frequency & Percentage \\
\hline Tea type & 28 & \\
Chinese tea & 15 & 31.11 \\
Instant tea & 41 & 16.67 \\
Green tea & 6 & 45.56 \\
Others & & 6.66 \\
Consumption time & 15 & \\
Before 10:00 & 37 & 16.67 \\
10:00-13:00 & 34 & 41.11 \\
13:01-17:00 & 4 & 37.78 \\
17:01-20:00 & 0 & 4.44 \\
After 20:00 & & 0.00 \\
Frequency of weekly consumption & 12 & \\
1-2 & 46 & 13.33 \\
3-5 & 32 & 51.11 \\
>5 & & 35.56 \\
Buying means & 72 & \\
By himself/herself & 18 & 80 \\
By others & & 20 \\
Places where the tea was bought & 12 & 13.33 \\
Convenient stores & 8 & 8.89 \\
Co-op food stores & 61 & 67.78 \\
Supermarkets & 5 & 5.56 \\
Grocery stores & 4 & 4.44 \\
Other places & & \\
\hline
\end{tabular}


Table 7: Levels of acceptance of the lotus pollen tea product

\begin{tabular}{lcc}
\hline Factors & Frequency & Percentage \\
\hline Level of acceptance & & \\
Most acceptable & 0 & 0.00 \\
Very acceptable & 15 & 16.67 \\
Fairly acceptable & 45 & 50.00 \\
Just acceptable & 22 & 24.44 \\
Not acceptable & 8 & 8.89 \\
Buying intention & & \\
Yes & 25 & 27.78 \\
No & 28 & 31.11 \\
Uncertain & 37 & 41.11 \\
\hline
\end{tabular}

purchase of organic tea. However, many factors effect the purchase behavior of consumers and consumption of organic tea (Sakthirama et al., 2013). Pual and Rana (2012) indicated that healthy attributes, availability of products and education had positively influence the consumer's attitude towards buying organic food. Income, age and willing to pay at a premium price for safe food had minor effect on the purchase of organic food (Lockie et al., 2004). Sheng-Hun et al. (2010) stated that the negative relationship between price and purchasing intention whereas respondents from Taiwan preferred tea drinking products with health benefit claims. The consumer goes through different buying decision process before he makes a decision to purchase a product. Further research should be conducted on various types of buying influences to develope market strategies to target consumers (Sumi and Kabir, 2010).

\section{CONCLUSIONS}

Growing lotus for pollen production organically is laborious and time consuming, but the growers can save the costs of pesticides and synthetic fertilizers. In this study, we found that there were thrips infesting the pollens, but they were easily removed. Based on its pollen yield, antioxidant capacity, total polyphenol content, and 9-point hedonic rating, the Buntharik organic pollen tea was chosen as a viable consumer product. The product acceptance study gained basic information for further development of organic lotus pollen tea into a truly marketable product. If fully developed, the tea may be preferred by people over 30 years of age. Campaigns on health benefits of the lotus pollen tea should be staged, offering the tea as a healthy substitute for unhealthy beverages. Comprehensive market research and development for product diversity should also be conducted.

\section{ACKNOWLEDGEMENT}

We thank Ms. Sayomoporn Pleansri and Mr. Praphunsak Chormalee for their assistance in data analysis and manuscript preparation.
This study was funded by Faculty of Agricultural Technology, King's Mongkut's Institute of Technology Ladkrabang.

\section{Author contributions}

D.H.: Designed and wrote the manuscript and S.B.: Conducted the research work and did statistical analysis.

\section{REFERENCES}

Anesini, C., G. E. Ferraro and R. Filip. 2008. Total polyphenol content and antioxidant capacity of commercially available tea (Camellia sinensis) in Argentina. J. Agric. Food Chem. 56: 9225-9229.

Arazo, M., A. Bello, L. Rastrelli, M. Montelier, L. Delgado and C. Panfet. 2011. Antioxidant properties of pulp and peel of yellow mangosteen fruits. Emirates J. Food Agric. 23: 517-524.

Beltrán-Orozco, M. C., J. J. OcampoRascón, F. D. DaízCedillo and R. S. Torres. 2013. Chemical composition and antioxidant ability of the crude extract of Sedum praealtum flowers. Emirates J. Food Agric. 25: 778-784.

Boots, A. W., G. R. Haenen and A. Bast. 2008. Health effect of quercetin: From antioxidant to nutraceutical. Eur. J. Pharmarcol. 13585: 325-337.

Brand-Williams, W., M. E. Cuvelier and C. Berset. 1995. Use of free radical method to evaluate antioxidant activity. Lebenson. Wiss. Technol. 28: 25-30.

Bumroongsook, S. 2003. Protection of Lotus Production from by Insect Pests Used Mechanical and Cultural Control. KMITL Research Report.

Cabrera, C., R. Gimenez and C. M. Lopez. 2003. Determination of tea components with antioxidant activity. J. Agric. Food Chem. 51: 4427-4435.

Department of Medical Science. 2004. Thai-Chinese Herbs. Foundation of Medical Science, Bangkok.

Hadyanyah, E. 2009. A marketing strategy to increase buyers's purchasing power of organic products by public opinion and approach. In: The International Symposium on the Approach of Organic Agriculture: New Markets, Food Security and a Clean Environment.

Karori, S. M., F. N. Wachira, J. K. Wanyoko and R. M. Ngure. 2007. Antioxidant capacity of different types of tea products. Afr. J. Biotechnol. 6: 2287-2296.

Lockie, S., G. Lawrence and J. Grice. 2004. Choosing organic: A path analysis of factors underlying the seletion of organic food among Australian consumers. Appetite, 143: 135-146.

Malhi, S. S., S. A. Brandr, R. P. Zentner, J. D. Knight, K. S. Gill, T. S. Sahota and J. J Schoenua. 2009. Managing Strategies and Practices for Preventing Nutrient Deficiencies in Organic Crop Production. In: The International Symposium on the Approach of Organic Agriculture: New Markets, Food Security and a Clean Environment.

Miean, K. S. and S. Mohamed. 2001. Flavonoid (myricetin, quercetin, kaempferol, luteolin, and apigenin) content of edible tropical plants. J. Agric. Food Chem. 49: 3106-3112.

Mungnimitr, S. and S. Bumroongsook. 2007. Identification of Frankliniella schultzei (Trybom) and Scirtothrip dorsalis Hood on Nelumbo nucifera Gaertn. by ITS-RFLP. In: The Proceeding of IWGS Annual Symposium 2007 on Potential Development of Lotus and Water lily as Economic Plants.

Newswit. 2007. Campaign to use Thai products to decrease the import of luxury items. Available from: http://www.sme.go.th/ cjournal_articles/view_content?article_id.

Pual, J. and J. Rana. 2012. Consumer behavior and purchase intention for organic food. J. Consum. Mark. 29: 412-422. 
Pleansri, S. and S. Bumroongsook. 2013. Thrips Distribution on 4 Varieties of Sacred Lotus Flowers (Nelumbonucifera) In: The Proceeding of the $11^{\text {th }}$ Naresuan University. Agriculture Annual Conference, Naresuan University.

Sakthirama, V., R. Venkatram and S. D. Sivakumar. 2013. Factor affecting the regularity of purchase of organic tea. Int J. Manage. 4: 14-19.

Sheng-Hung, C., C. Hsin-Fan and W. Hui-Cheng. 2010. Do health claims matter for consumer preference on tea beverage? Experimental evidence from Taiwan. In The $115^{\text {th }}$ Joint EAAE/AAEA Seminar, September 15-17, 2010, FreisingWeihenstephan, Germany.

Singleton, V. L., Orthfer, R. and R. M Lamuela-Raventos. 1999. Analysis of total phenoland other oxidation substrates and antioxidants by means of folin-ciocateu reagent. Methods. Enzymol. 299: 152-178.

Sumi, R. S. and G. Kabir. 2010. Analytical hierarchy process for higher effectiveness of buyer decision process. Global. J. Manage. Bus Res. 10: 1-9.
Thongrungroj, S. 2007. Chemical Constituents of Volatiles Substances from Nelumbo nucifera Stamens. MS Thesis, Phranakhon Rajabhat University.

Tokuşoğlu, Ö., M. K. Ünal, and Z. Yıldırım. 2003. HPLC-UV AND GC In-MS characterization of the flavonol aglycons, quercetin, kaemperol, and myricetin in tomato pastes and other tomatobased products. Acta Chromatogr. 13: 196-207.

Verlangieri, A. J., J. C. Kapeghian, S. Bel-Dean and M. Bush. 1985. Fruit and vegetable consumption and cardiovascular mortality. Med. Hypotheses. 16: 7-15.

Walsh, K., N. Boonham, I. Barker and D. W. Collins. 2005. Development of a sequence-specific real-time PCR to the melon Thrips, Thrips palmi (Thysan. Thripidae). J. Appl. Entomol. 129: 272-279.

Zhang, M., S. Q. Swarts, L. Yin, C. Liu, Y. Tian, Y. Cao, M. Swarts, S. Yang, S. B. Zhang, K. Zhang, S. Ju, D. J. Olex, L. Schwartz. P. C. Ken, R. Howell, L Zhang and P. Okunieff. 2011. Antioxidant properties of quercetin. Adv. Exp. Med. Biol. 701: 283-289. 